\title{
TARI BALI: \\ TANTANGAN DAN SOLUSI DI ERA GLOBALISASI
}

\author{
Oleh: \\ I Gusti Made Bagus Supartama \\ ajikguslanang@gmail.com \\ UNHI Denpasar \\ I Wayan Sukadana \\ nanounhi108@yahoo.com \\ UNHI Denpasar
}

\begin{abstract}
ABSTRAK
Globalisasi dibangun dengan karakteristik ekonomi untuk mengintegrasikan bebagai elemen kehidupan kedalam system tunggal yang breskala dunia. Dengan demikian, maka akan terjadi eksploitas budaya local yang dikemas secara sistematis dalam bentuk komoditi kapitalis. Sesungguhnya hal ini merupakan ancaman terhadap keutuhan dan keaslian budaya lokal beserta pilar-pilar identitas yang membangunnya. Hal ini sangat nampak pada kesenian khususnya seni tari sebagai identitas budaya Bali, sehingga memerlukan revitalisasi terhadap tari Bali melalui konsensus bersama antara intelektual, seniman, tokoh-tokoh agama, beserta para pengusaha untuk merumuskan kembali kesenian dalam menghadapi era globalisasi.
\end{abstract}

Kata Kunci: tari Bali, kearifan lokal, tantangan, solusi, globalisasi

\section{ABSTRACT}

Globalization is built with economic characteristics to integrate various elements of life into a single, world-wide system. Thus, there will be exploitation of local culture systematically packaged in the form of capitalist commodities. In fact this is a threat to the integrity and authenticity of the local culture along with the pillars of identity that build it. This is very visible in the arts, especially dance as a Balinese cultural identity, so that it requires revitalization of Balinese dance through a mutual consensus between intellectuals, artists, religious leaders, and entrepreneurs to reformulate the arts in the face of globalization.

Keywords: Balinese dance, local wisdom, challenges, solutions, globalization

\section{PENDAHULUAN}

Perkembanagan teknologi mutahir sebagai panglima revolusi dunia telah menghantarkan umat manusia menjadi konsumerisme sebagai akibat dari tekanan industrialisasi yang merupakan karakteristik moderenisasi abad 20.
Semua aspek kehidupan manusia digulirkan, sehingga populasi manusia berlebihan, kerusakan lingkungan tambah parah, kapitalisme merajalela, dan tekanan internasional yerus berkelanjutan menyebabkan sebagian besar umat 
manusia tidak berdaya melawan arus (Laszio, 1999).

Tari Bali sebagai salah satu kekayaan budaya yang bernafaskan agama dan kebudayaan Hindu juga digulirkan oleh kondisi tersebut. Datangnya wisatawan asing dengan budaya modern yang didorong oleh industrialism di dunia Barat,telah mengembangkan tari Bali memiliki posisi tawar yang sangat tinggi sebagai konsumsi wisata. Sebagai sebuah proses kesenian tidak muncul begitu saja sebagai hasil kreativitas estetik, tetapi juga memperhatikan system budaya dan norma-norma sosialyang menyebabkan tari Bali memiliki posisi tawar yang cukup tinggi dari pariwisata di Bali. Sistem budaya dan norma-norma sosial merupakan gejala kemasyarakatan yang memberikan isi pada tari Bali yang membedakan dengan tari lainnya. Dengan demikian secara sosiologis hubungan antara seni tari dengan kehidupan masyarakat dapat dilihat dari kecendrungan isi pada karya seni tari yang memiliki makna tersendiri sebagai pembentuk identik.

Dengan demikian tari Bali berkembang sebagai sarana pengabdian sosial baik untuk kepentingan upacara keagamaan maupun untuk kegiatankegiatan sosial yang lebih mengarah pada fungsinya sebagai media komunikasi makna budaya dan hiburan pada masyarakat. Tari Bali dalam arti seniman dan ciptaannya tidak pernah memperhitungkan untung rugi dari sisi eknomi, tetapi lebih memperhitungkan kepuasan masyarakat dalam menikmati hasil kreatifnya. Apakah kondisi seperti ini akan dapat dipertahankan di era Globalisasi, merupakan sebuah kegalauan sosial karena globalisasi mengembangkan sayapnya untuk menguasai dunia melalui kekuatan kapitalis yangakhirnya menjelma menjadi imperialisme kapitalis. Konsekensinya adalah muncul imprialisme budaya yang merupakan hasil dari proses budaya dan ekonomi yang disebabkan oleh reproduksi kapitalisme global (Barker, 2004 : 117). Implikasinya adalah tari Bali diproduksi kembali bukan untuk memenuhi kebutuhan sosial dan keagamaan, tetapi untuk memenuhi kebutuhan ekonomi yang dikendalikan oleh kapitalis. Hal inilah yang merupakan tantangan bagi tari Bali di era gobalisasi.

\section{PEMBAHASAN}

\subsection{TANTANGAN BUDAYA LOKAL DI ERA GLOBAL}

Globalisasi adalah proses terintegrasinya berbagai elemen kehidupan kedalam sistem tunggal yang berskala dunia. Sistem tunggal ini dimotori oleh perkembangan kapitalisme dan tehnologi informasi yang mendorong munculnya imprialisme kapitalis. Kapitalisme dibangun diatas prinsip persaingan bebas yang didalamnya melekat kehendak untuk menguasai pasar, kehendak untuk mendominasi pihak lain, kehendak untuk mendapatkan keunggulan dan kekayaan sebagai akomulasi capital sebesar-besarnya (Piliang, 2011 : 210). Usaha untuk mengakomulasi capital sebesar-besarnya menyebabkan munculnya strategi untuk menarik konsumen agar mengkonsumsi produk kapitalisme tidak hanya yang menyangkut kebutuhan hidup seperti benda-benda ekonomi, tetapi juga menyangkut seluruh aspek kehidupan termasuk juga tindakan budaya : cara bertindak, sopan santun, cara berbicara, sikap, mentalitas, aspirasi dan persepsi. Dengan demikian ancaman kapitalisme terhadap budaya lokal tidak hanya pada macro culture, seperti : idiologi, keyakinan, paham, tetapi juga pada micro culture yaitu cara hidup sehari-hari (cara berpakaian, cara bertindak, cara berkesenian dsb) (Piliang, 2010 : 207).

Disini kesenian Bali khususnya seni tari mulai terancam, tari Bali mulai menjadi seni pesanan, nilai-nilai estetik pada tari Bali tidak ada lagi ditentukan oleh pencipta karya seni, tetapi 
ditentukan oleh pemesan. Pemesannya adalah kapitalis, karena tari Bali telah masuk menjadi komoditi (barang) yang bisa diperjual belikan. Disini kapitalisme monopoli, berubah menjadi kapitalisme kompetetif artinya tidak hanya satu atau beberapa perusahaan yang mengandalkan pasar, tetapi bergeser pada bidang penjualan karena itu periklanan, pengemasan, dan metode lain yang bertujuan untuk menarik minat konsumen potensial menjadi sangat penting dalam kapitalisme ko,petetif (Ritzer dan Goodman, 2010: 193-194). Kondisi ini menyebabkan semua hal bisa dikemas untuk diperjual belikan termasuk tari Bali yang telah disepakati sebagai seni sakral, dikemas dengan membuat imitasi-imitasi untuk memenuhi kebutuhan pasar.

Disamping itu kesenian Bali, khususnya seni tari dibonsai atau dipotong-potong sesuai dengan kebutuhan pasar (wisatawan). Misalnya tari Legong Kraton, yang kiranya dipentaskan satu setebgah jam, kemudian dikemas menjadi sepuluh menit karena kebutuhan wisata. Inilah bahaya bagi kesenian Bali khususnya seni tari yaitu kaburnya seni sakral dan provan, serta tri Bali akan tercabut dari akar yang sebenarnya, sehingga pemahaman masyarakat di masa yang akan datang terhadap tari Bali adalah seperti apa yang terjadi sekarang.

Terjadinya transformasi budaya, dari budaya tradisional yang dipolakan sebagai tradisi besar dan tradisi kecil ke budaya modern yang dipolakan sebagai budaya rasional, consumer dan individual telah menciptakan dialektika dan perubahan pada tari Bali. Dalam dialektika dan perubahan budaya ini kesenian khususnya tari diarahkan pada kebutuhan untuk memenuhi tujuan kehidupan manusia (telos).Kebutuhan hidup manusia sangat kmpleks dan terdifrensiasi kedalam berbagai sector, sehingga kesenianpun sebagai salah satu sector dalam kehidupan manusia juga tunduk pada tujuan manusia. Pada saat tujuan manusia mengarah pada kebutuhan untuk mempertahankan, melestarikan dan mengembangkan nilainilai budaya, maka seni tari dapat digunakan untuk memberikan arah pada tujuan tersebut (Kartodirdjo, 1992 : 163). Ketika lingkungan sosial berubah, kehidupan manusia sangat dipengaruhi oleh perkembangan pariwisata, maka seni tari tunduk pada kebutuhan manusia untuk mensukseskan pariwisata, sehingga tari Bali bukan lagi terikat pada nilai-nilai dan norma-norma budaya dan agama Hindu Bali, tetapi terikat pada kebutuhan pasar yaitu wisatawan.

Tari Bali yang memiliki daya pikat tersendiri menyebabkan wisatawan mulai berdatangan ke Bali untuk melihat dan menikmati secara langsung tari Bali dengan menggandeng system kapitalisme yang kemudian mengkemas tari Bali menjadi komoditi untuk bisa masuk pasar global. Kondisi seperti ini kemudian mengalami perubahan sebagai hasil spontanitas dari evolusi modernitas, dan dipercepat lagi oleh kekuasaan kolonialisme yang menjadikan Bali sebagai obyek intrinsic dari ruang ekonomi dan kultur dunia luar, sehingga Bali dilemparkan sebagai komoditas dipasaran internasional (Wiryanaya dan Coeteu, 1995 : 57). Apabila kecendrungan seperti ini berlanjut terus : budaya konsumerisme, budaya citra, budaya tontonan yang diciptakan oleh kapitalisme pada individu-individu di dalam masyarakat, maka proses produksi global sama artinya dengan proses penghancuran budaya local (Piliang, 2004 : 210).

\subsection{SOLUSI DAN HARAPAN PADA TARI BALI}

Memahai seni tari Bali sebagai salah satu identitas budaya Bali adalah memahami kesenian sebagai hasil dari akumulasi peristiwa budaya, sosial, ekonomi dan politik yang dipengaruhi oleh kepribadian orang Bali yang dilandasi oleh nilai budaya yang telah 
dibentuk oleh proses sejarah (Wayang, 2002 : 84). Revitalisasi tari Bali berarti membangkitkan kembali identitas tari Bali yang dianggap telah dirongrong oleh kapitalisme global sebagai akibat berkembangnya pariwisata di Bali. Kita bukan menolak pariwisata tetapi kita harus mulai memahami bahwa identitas menurut Jonhatan dan Rutherford, merupakan mata rantai yang menghubungkan nilai-nilai sosial budaya masa lalu dengan masa sekarang (Piliang, 2010 : 211). Perubahan kesenian khususnya tari Bali sebagai identitas budaya tidak terjadi hanyakarena pengaruh system kapitalis, tetapi perubahan identitas bisa terjadi dari dalam kebudayaan itu sendiri. Budaya sebagai pandangan Ideasional sebagai panduan untuk menyelesaikan tujuantujuan hidupnya, manusia membuat benda-benda dan barang-barang, mengubah lingkungan fisiknya, menciptakan kelompok sosial, membuat aturan yang mengarahkan berjalannya hubungan antara manusia satu dengan lainnya. Mereka juga menciptakan dongeng-dongeng, dan legnda, mitosmitos, resep-resep makanan, ritualitasritualitas yang mengungkapkan keyakinan dan kepercayaan manusia.

Geertz, menganggap bahwa budaya adalah jalinan makna (fablic of meaning), dalam pengertian bahwa manusia menafsirkan pengalamannya untuk memandu tindakannya, sedangkan struktur sosial adalah tempat tindakan itu terjadi yaitu jaringan hubunganhubungan sosial yang hadir secara actual (Hasan, 2011 : 20). Perubahan tujuantujuan hidup manusia, merubah juga manusia memaknai pengalamannya dalam memandu tindakannya. Misalnya kesenian, khususnya seni tari yang semula merupakan kegiatan pengabdian pada masyarakat menjadi kegiatan kesenian yang diproduksi untuk bisa dijual. Kondisi seperti ini menyebabkan munculnya sinyalemen yang mengatakan bahwa dari budaya "ngayah" menjadi "mebayah". Dengan demikian maka kesenian sebagai sebuah identitas budaya menurut Stuart Hall, tidak pernah stabil, tidak pernah sempurna ia selalu berproses menjadi dan menjadi dan dia selalu dibangun dari dalam kebudayaan itu sendiri (Piliang, 2010 : 212).

Seni tari sebagai sebuah identitas budaya selalu bergulat dengan perkembangan sejarah dan perkembangan sejarah sangat ditentukan oleh jiwa jaman, karena itu seni tari akan berubah sesuai dengan perkembangan jaman. Yang menjadi persoalan dalam perubahan seni tari Bali bukan menolak perubahan, tetapi sejauh mana perubahan itu dapat diterima sebagai usaha untuk mempertahankan keutuhan seni tari Bali, originalitas, serta nilai-nilai agama dan budaya Hindu yang melekat dengan hasil-hasil kesenian yang dikembangkan di era globalisasi. Untuk mengantisipasi perubahan yang tidak kita inginkan sebagai dampak dari derasnya arus globalisasi melalui imperialism kapitalis, maka Prof Bagus pernah menulis dalam buku, Bali di Persimpangan Jalan jilid I (sebuah bunga rampai) mengatakan bahwa perlu proses konsulidasi agama Hindu, karena agama Hindu berfungsi memberikan semangat dan dorongan lewat proses pembakuannya dalam bentuk sistematis, restrukturisasi, reinterpretasi, dan refungsionalisasi dan sebagai pendukung adalah kelas baru dan elite-elie baru yang muncul sebagai intelektual dan pemikirannya dapat dijadikan tauladan. Prof Bagus juga berharap aka nada pertemuan sekelompok orang yang terkemuka dalam bidang ilmu sosial, politikus, humaniora, eksakta, seniman-seniman besar yang dipandu oleh teolog Hindu untuk membincangkan berbagai masalah pembangunan, tidak hanya ditingkat local, dan nasional, tetapi untuk seluruh umat manusia (Wiryaynaya dan Coeteau, 1995 : 75).

Kalau disimak pandangan Prof Bagus di atas maka yang penting adalah 
bagaiman kita memaknai kesenian Bali khususnya tari Bali sebagai identitas budaya, melalui penafsiran kembali dan strukturisasi kembali, dan menata kembali fungsi-fungsi tari Bali, melalui pertemuan dan kesepakatandalam mengahdapi era globalisasi dan era imprialisme kapitalis. Untuk itu kita perlu mengubah paradigm kehidupan sosial itu sendiri, yang artinya masyarakat local tidak lagi menggantungkan masa depannya pada paradigm kapitalis tetapi harus dikembangkan indicator kemajuan yang digali dari system local yang lebih sesuai dengan nilai-nilai budaya local. Yang paling penting adalah mengubah cara berpikir masyarakat local, karena perubahan mendasar pada budaya dan kesenian Baliterletak pada perspektif nilai dan tindak tanduk individu (Piliang, 2010, 210-211).

\section{PENUTUP}

Kesenian Bali khususnya seni tari telah menyatu dan melekat dengan kehidupan masyarakat Bali yang beragama Hindu. Setiap upacara agama Hindu, selalu melibatkan kesenian sebagai bagian dari upacara tersebut, sehingga seni tari berhasil menempatkan diri sebagai identitas budaya Bali yang intinya adalah nilai-nilai agama Hindu. Globalisasi dibangun dengan karakteristik ekonomi untuk mengintegrasikan bebagai elemen kehidupan kedalam system tunggal yang breskala dunia. Dengan demikian, maka akan terjadi eksploitas budaya local yang dikemas secara sistematis dalam bentuk komoditi kapitalis. Sesungguhnya hal ini merupakan ancaman terhadap keutuhan dan keaslian budaya lokal beserta pilarpilar identitas yang membangunnya. Hal ini sangat nampak pada kesenian khususnya seni tari sebagai identitas budaya Bali, sehingga memerlukan revitalisasi terhadap tari Bali melalui konsensus bersama antara intelektual, seniman, tokoh-tokoh agama, beserta para pengusaha untuk merumuskan kembali kesenian dalam menghadapi era globalisasi.

\section{DAFTAR PUSTAKA}

Barker, Cris. 2004. Cultural Studies, Teori dan Praktek. Yogyakarta: Kreasi Wacana.

Wiryatnaya, Usadi dan Jean Couteau. 1995. Bali Di Persimpangan Jalan ( Sebuah Bunga rampai Jilid 1 dan 2). Denpasar: Nusa Data Indobudaya.

Piliang, Yasraf Amir. 2011. Dunia Yang Dilipat, Tamsya Melampaui Batas Batas Kebudayaan. Bandung: Matahari.

Bakhtiar, Amsal. 2010. Filsafat Ilmu. Jakarta: Raja Granfindo Persada.

Hasan, Sandi Suwandi. 2011. Pengantar Culture Studies, Sejarah, Pendekatan dan Isu Menuju Studi Budaya Kapitalisme Lanjut. Yogyakarta: Ar-Ruzz Media.

Ritzer, George dan Doglas J. Goodman. 2010 Teori Sosiologi Modern. Jakarta: Kencana Prenada Media Group.

Seramasara, I Gusti Ngurah. 2002. "Paradigma Kesenian Bali di Era Globalisasi Sebuah Dialektika Budaya," dalam Jurnal Wayang, Wacana Ilmiah Pewayangan. Denpasar: Jurusan Pedalangan Sekolah Tinggi Seni Indonesia Denpasar. 
Kartodirdjo, Sartono. 1982. Pemikir dan Perkembangan Historiografi Indonesia Suatu Alternatif. Jakarta: PT Gramedia. 